\title{
Analisis Pengaruh Tingkat Daya Pada Pengeringan Dengan Oven Microwave Terhadap Kualitas Gaplek Uwi Ungu
}

\section{(Analysis the influence of Power level on the Drying Process by Using Microwave Oven on the Quality of the Purple Yam Gaplek)}

\author{
Rizkia Marisa ${ }^{1}$, Bambang Sukarno Putra ${ }^{1}$, Rita Khathir $^{1 *}$ \\ ${ }^{1}$ Program Studi Teknik Pertanian, Fakultas Pertanian, Universitas Syiah Kuala \\ *Corresponding author: bambangtp@unsyiah.ac.id
}

\begin{abstract}
Abstrak. Tujuan penelitian ini adalah untuk mengetahui pengaruh daya pada pengeringan menggunakan oven microwave terhadap kualitas gaplek uwi ungu. Metode yang dilakukan adalah melakukan pengeringan uwi ungu $500 \mathrm{~g}$ dalam microwave oven frekuensi $2.450 \mathrm{MHz}$ selama 8 menit dengan variasi daya 300,450 dan $600 \mathrm{~W}$, di mana setiap perlakuan diberikan 3x ulangan. Pengamatan dilakukan terhadap kadar air, rendemen, kadar Vitamin $\mathrm{C}$, kadar karbohidrat, analisis warna $\mathrm{L}^{*} \mathrm{a} * \mathrm{~b}$, dan uji organoleptik (warna, tekstur dan aroma). Hasil penelitian menunjukkan bahwa perlakuan variasi daya microwave selama 8 menit berpengaruh nyata terhadap kadar air dan kadar karbohidrat, namun perlakuan tersebut tidak memberi pengaruh nyata terhadap faktor lain yang diuji yaitu rendemen, kadar vitamin $\mathrm{C}$, warna dan uji organoleptik. Perlakuan terbaik adalah pada penggunaan daya $300 \mathrm{~W}$.
\end{abstract}

Kata Kunci: Gaplek uwi ungu, Pengeringan, Microwave, Daya

\begin{abstract}
The purpose of this study was to determine the influence of power level on drying by using microwave oven on the quality of purple yam gaplek. About 500g of purple yam was dried in a microwave oven with a frequency of $2,450 \mathrm{MHz}$ for 8 minutes under the power level variation of 300,450 and $600 \mathrm{~W}$, with 3 replications. Observations were made on water content, yield, Vitamin C content, carbohydrate content, $\mathrm{L}^{*} \mathrm{a} * \mathrm{~b}$ color and organoleptic tests (color, texture and aroma). The results showed that the variation of microwave power for 8 minutes had a significant effect on water content and carbohydrate content, but the treatment did not significantly affect other factors tested, namely yield, vitamin $\mathrm{C}$ content, color and organoleptic tests. The best treatment was at power level of $300 \mathrm{~W}$.
\end{abstract}

Keywords : Purple Yam, Drying, Microwave, Power

\section{PENDAHULUAN}

Menurut French (2006), uwi termasuk ke dalam famili Dioscoraeceae Genus. Dioscorae yang memiliki lebih dari 600 jenis, yang 10 jenis diantaranya digunakan sebagai produk pangan dan untuk obat-obatan. Uwi ungu memiliki karakteristik yaitu uwi bulat tidak beraturan, lonjong, elips dan oval, serta bercabang 2-3. Kulit dari uwi ungu berwarna coklat hingga ke coklat tua dan permukaan kulit beralur kasar. Daging umbinya berwarna putih dengan bintik-bintik keunguan sampai ungu tua dan berlendir. Uwi ungu ini memiliki tekstur lembut dan rasa yang hambar. Umur panen uwi ungu Antara 180-270 hari dan merupakan tanaman pangan tahunan.

Pengeringan merupakan suatu proses pengurangan air dari bahan dengan jumlah yang relatif kecil menggunakan daya panas. Bahan kering yang memiliki kadar air setara terhadap kadar air keseimbangan udara normal yang aman dari kerusakan mikrobiologis, enzimatik dan kimia (Thamrin, 2011).

Microwave merupakan alat pengolahan pangan yang memiliki gelombang pendek pada proses memanaskan (Siswantoro, 2008). Prinsip pemanasan gelombang mikro adalah berdasarkan tumbukan langsung dari bahan ataupun pelarut polar dapat diatur oleh dua 
fenomena yaitu konduksi ionik dan putaran dipol. Dalam sebagian besar kasus, kedua fenomena tersebut berjalan secara bersamaan (Quoc, 2014).

Gaplek uwi ungu merupakan irisan tipis uwi ungu kering yang dapat diolah lebih lanjut menjadi berbagai produk pangan antara lain kue kering, muffin, cake, sari buah dan velva (Fauzi dkk., 2017). Tujuan penelitian ini adalah mengetahui pengaruh daya pada pengeringan menggunakan oven microwave terhadap kualitas gaplek uwi ungu.

\section{METODE PENELITIAN}

Penelitian ini telah dilaksanakan pada bulan September sampai dengan November 2020 bertempat di Laboratorium Teknik Pacsa Panen, Program Studi Teknik Pertanian, Fakultas Pertanian, Universitas Syiah Kuala, Darussalam, Banda Aceh serta Laboratorium Analisis Pangan dan Hasil Pertanian, Program Studi Teknologi Hasil Pertanian, Fakultas Pertanian, Universitas Syiah Kuala, Darusalam, Banda Aceh. Alat yang digunakan pada penelitian ini adalah oven microwave merk Samsung ME731K dengan frekuensi pengoperasian 2.450 $\mathrm{MHz}$, sumber daya $230 \mathrm{Vol}-50 \mathrm{~Hz}$, dan ruang oven mempunyai volume 20 liter. Peralatan pendukung lainnya adalah mangkuk kramik, timbangan digital, termometer, stopwatch, slicer. Sedangkan bahan yang digunakan dalam penelitian ini adalah uwi ungu sebanyak $4,5 \mathrm{~kg}$. Rancangan percobaan yang digunakan pada penelitian ini adalah Rancangan Acak Lengkap (RAL) Non Faktorial, di mana melihat pengaruh 1 faktor yaitu pemberian daya pada 3 tingkatan, 300, 450, dan $600 \mathrm{~W}$.

\section{Prosedur Penelitian}

Tahap pertama yaitu persiapan bahan berupa sortasi terlebih dahulu dengan tujuan untuk memisahkan antara kualitas yang baik, bebas dari hama, tidak busuk dan dihitung berat awal uwi ungu. Selanjutnya dilakukan pengupasan untuk memisahkan kulit dengan daging uwi. Uwi ungu yang sudah bersih lalu diukur kadar air awalnya sebelum dilakukan proses pengeringan hingga mencapai kadar air 14\%. Kemudian dilakukan pengirisan dengan slicer dengan ketebalan $3 \mathrm{~mm}$. Uwi ungu yang telah diiris kemudian diblanching dalam air panas selama 10 menit dengan suhu $80^{\circ} \mathrm{C}$, lalu ditiriskan. Selanjutnya $500 \mathrm{~g}$ uwi ungu dikeringkan dengan variasi daya $300 \mathrm{~W}, 450 \mathrm{~W}$ dan $600 \mathrm{~W}$ selama 8 menit menggunakan oven microwave. Setelah dilakukan proses pengeringan didapatkan gaplek uwi ungu yang kemudian dihitung kadar air akhir, rendemen, kadar vitamin $\mathrm{C}$, kadar karbohidrat, warna dan organoleptik (warna, tekstur dan aroma). Diagram alir penelitian dapat dilihat pada Gambar 1. 


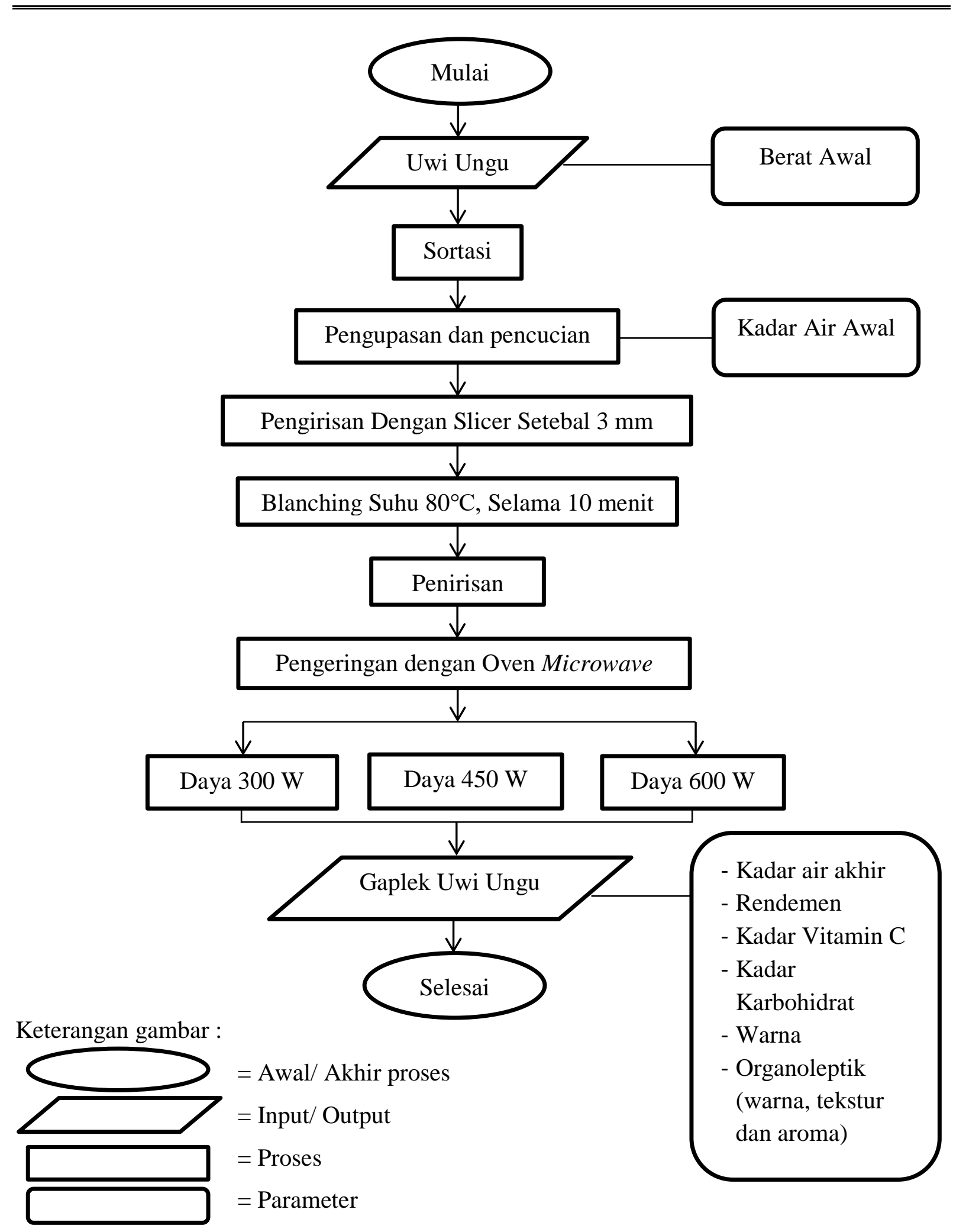

Gambar 1. Diagram Alir Penelitian 


\section{Parameter Penelitian}

\section{Kadar Air}

Prosedurnya ialah bahan ditimbang sebanyak $5 \mathrm{~g}$ di dalam mangkuk keramik yang telah diketahui berat kosongnya. Kemudian bahan tersebut dikeringkan dalam oven dengan suhu sekitar $105^{\circ} \mathrm{C}$ selama 3 jam. Selajutnya didinginkan di dalam desikator selama 15 menit lalu ditimbang kembali. Selanjutnya, bahan dipanaskan kembali ke oven selama 30 menit, setelah itu didinginkan kembali menggunakan desikator selama 15 menit lalu ditimbang. Proses ini diulangi sampai berat konstan tercapai (AOAC, 2005). Kadar air dihitung dengan persamaan 1.

Kadar $\operatorname{Air}_{\mathrm{bb}}(\%)=\frac{\text { berat awal-berat akhir }}{\text { berat awal }}$ X $100 \%$

\section{Rendemen}

Rendemen adalah jumlah produk yang diperoleh setelah serangkaian proses pengolahan, dalam hal ini rendemen dimaksudkan adalah banyaknya gaplek uwi ungu yang diperoleh. Perhitungan rendemen gaplek uwi ungu dihitung dengan Persamaan 2.

$\mathrm{R}=\frac{W b}{W a} \mathrm{X} 100 \%$

\section{Kadar Vitamin C}

Analisa kadar Vitamin $\mathrm{C}$ dilakukan dengan menggunakan metode titrasi iodimetri. Tritrasi iodimetri adalah titrasi redoks dengan 12 sebagai pentiternya. Sedangkan untuk indikatornya menggunakan larutan amilum. Amilum digunakan sebagai indikator karena akan membentuk kompleks iod amilum yang berwarna biru tua meskipun konsentrasi 12 sangat kecil dan molekul iod terikat kuat pada permukaan beta amilosa seperti amilum. Deteksi titik akhir titrasi pada iodium dengan menggunakan amilum adalah perubahan warna menjadi biru tua (AOAC, 1995).

$\%$ Vitamin $\mathrm{C}=\frac{\text { Vol tirtasi iodium } \times 0,88}{\mathrm{mg} \text { sampel }} \times 100$

\section{Kadar Karbohidrat}

Menurut Winarno (1996), penentuan kadar karbohidrat dihitung menggunakan by difference dengan rumus 4 .

Karbohidrat $(\%)=100 \%-($ kadar air + kadar protein + kadar abu + kadar lemak $)$

\section{Warna}

Analisis warna $\mathrm{L}^{*} \mathrm{a} * \mathrm{~b}$ dilakukan dengan photoshop berdasarkan hasil pemotretan setiap sampel gaplek uwi ungu.

\section{Uji Organoleptik}

Uji organoleptik dilakukan terhadap 30 orang responden dengan memberikan display sampel gaplek dan 1 lembar kuisioner. 


\section{HASIL DAN PEMBAHASAN}

\section{Kadar Air Gaplek Uwi Ungu}

Kadar air awal uwi ungu sebelum perlakuan yaitu sebesar 78\%. Rerata kadar air akhir gaplek uwi ungu yang didapatkan dari hasil penelitian ini adalah sebesar 10,68\%, di mana kadar air tersebut tidak melebihi standar SNI untuk kadar air gaplek. Untuk nilai kadar air pada perlakuan daya $300 \mathrm{~W}$ yaitu sebesar $12,02 \%$ kadar air pada perlakuan daya $450 \mathrm{~W}$ sebesar $10,84 \%$ dan kadar air sebesar $9,18 \%$ pada perlakuan $600 \mathrm{~W}$.

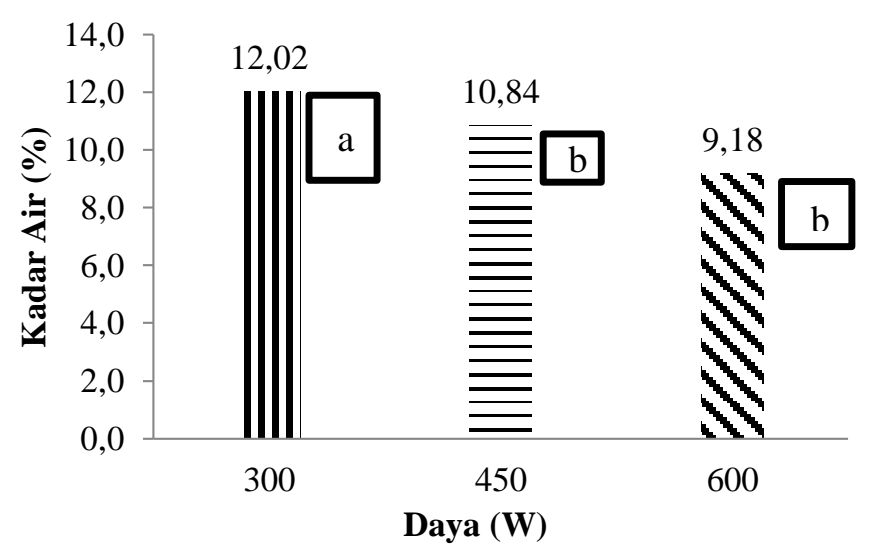

Gambar 2. Kadar Air Gaplek Uwi Ungu Pada Pengeringan Microwave Akibat Pengaruh Variasi Daya.

Berdasarkan analisis sidik ragam yang telah dilakukan menunjukkan bahwa daya microwave berpengaruh nyata $(\mathrm{P}>0,05)$ terhadap kadar air gaplek uwi ungu. Grafik notasi kadar air gaplek uwi ungu pada Gambar 2, menunjukkan perlakuan $300 \mathrm{~W}$ berbeda nyata dengan perlakuan $450 \mathrm{~W}$ dan $600 \mathrm{~W}$. Sedangkan pada perlakuan $450 \mathrm{~W}$ tidak berbeda nyata terhadap perlakuan $600 \mathrm{~W}$ ditandai dengan notasi yang sama pada perlakuan tersebut. Semakin tinggi daya yang digunakan maka semakin rendah kadar air di dalam bahan.

\section{Rendemen Gaplek Uwi Ungu}

Hasil grafik data rendemen gaplek uwi ungu dapat dilihat pada Gambar 3, nilai rendemen tertinggi gaplek uwi ungu terdapat pada daya $300 \mathrm{~W}$ yaitu sebesar 17,00\%. Rendemen gaplek uwi ungu pada daya $450 \mathrm{~W}$ adalah $16,33 \%$ sedangkan pada daya $600 \mathrm{~W}$ sebesar $16,00 \%$. Dimana rendemen gaplek uwi ungu tertinggi terdapat pada daya $300 \mathrm{~W}$ karena kadar air gaplek uwi ungu tertinggi pun terdapat pada daya $300 \mathrm{~W}$.

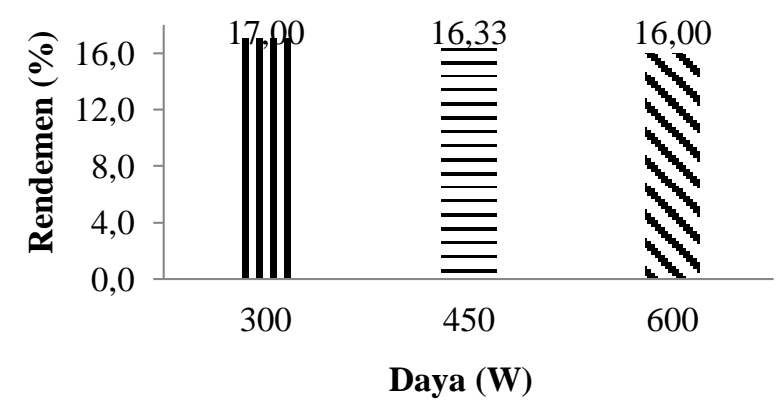

Gambar 3. Rendemen Gaplek Uwi Ungu Pada Pengeringan Microwave Akibat Pengaruh Variasi Daya. 
Nilai rendemen gaplek uwi ungu berbanding lurus dengan kadar air. Hal ini sesuai dengan pernyataan Martunis (2012), yang menyatakan bahwa perbedaan tinggi rendahnya rendemen suatu bahan pangan sangat dipengaruhi oleh kadar air suatu bahan pangan. Berat bahan kering seperti ukuran produk dan kadar air awal akan mempengaruhi proses pengeringan.

\section{Kadar Vitamin C Gaplek Uwi Ungu}

Berdasarkan grafik data kadar vitamin $\mathrm{C}$ gaplek uwi ungu diketahui bahwa kadar vitamin $\mathrm{C}$ sebesar 43,97 mg/100g didapatkan pada perlakuan daya $300 \mathrm{~W}$, kadar vitamin C pada perlakuan $450 \mathrm{~W}$ sebesar $43,38 \mathrm{mg} / 100 \mathrm{~g}$ sedangkan pada perlakuan daya $600 \mathrm{~W}$ didapatkan kadar vitamin $\mathrm{C}$ sebesar $39,27 \mathrm{mg} / 100 \mathrm{~g}$. Semakin tinggi penggunaan daya microwave maka semakin rendah kadar vitamin $\mathrm{C}$ yang terkandung di dalam gaplek uwi ungu. Hal tersebut sesuai dengan pernyataan Dina (2017), menyatakan bawha semakin tinggi daya maka kadar vitamin $\mathrm{C}$ yang terdapat dalam bahan akan semakin menurun karena semakin banyak kadar vitamin $\mathrm{C}$ yang terlarut bersama uap air yang dilepaskan dan juga semakin banyak kadar vitamin $\mathrm{C}$ yang rusak dikarenakan tingginya daya pada saat pengeringan.

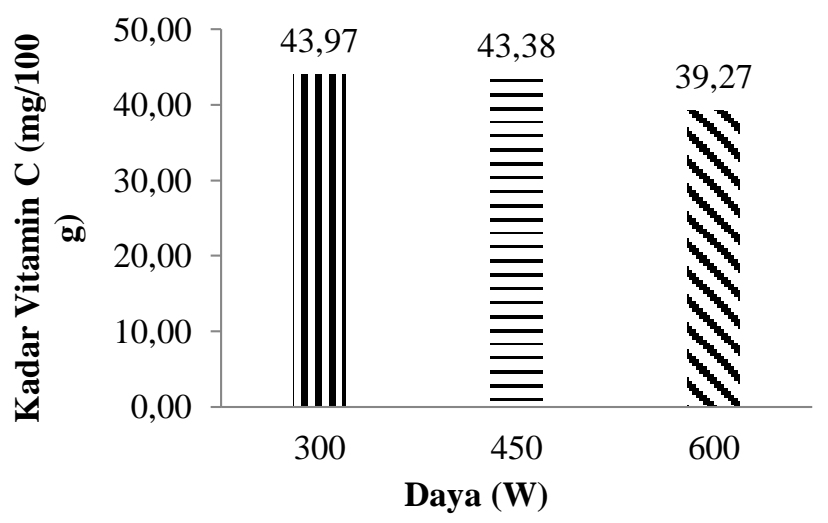

Gambar 4. Kadar Vitamin C Gaplek Uwi Ungu Pada Pengeringan Microwave Akibat Pengaruh Variasi Daya.

\section{Kadar Karbohidrat Gaplek Uwi Ungu}

Berdasarkan grafik data kadar karbohidrat gaplek uwi ungu pada Gambar 5, setelah pengeringan menunjukkan bahwa pada perlakuan daya $300 \mathrm{~W}$ sebesar $65,00 \%$, perlakuan daya $450 \mathrm{~W}$ sebesar 66,91 \% sedangkan pada perlakuan daya $600 \mathrm{~W}$ sebesar $69,12 \%$. Berdasarkan hasil penelitian tersebut terlihat bahwa semakin tinggi daya pengeringan kadar karbohidrat gaplek uwi ungu semakin tinggi.

Hasil uji lanjut Duncan menunjukkan bahwa nilai kadar karbohidrat perlakuan pada daya $300 \mathrm{~W}$ tidak berbeda nyata dengan perlakuan daya $450 \mathrm{~W}$, dan nilai kadar karbohidrat perlakuan pada daya $450 \mathrm{~W}$ tidak berbeda nyata dengan perlakuan daya $600 \mathrm{~W}$. Namun, kadar karbohidrat perlakuan daya $300 \mathrm{~W}$ berbeda nyata dengan kadar karbohidrat perlakuan daya $600 \mathrm{~W}$. Kadar karbohidrat gaplek uwi ungu diperoleh dari daya $600 \mathrm{~W}$ lebih tinggi dikarenakan kadar air paling rendah terdapat pada daya $600 \mathrm{~W}$ hal tersebut karena kadar air yang semakin rendah maka semakin besar terdapat padatan karbohidratnya. 


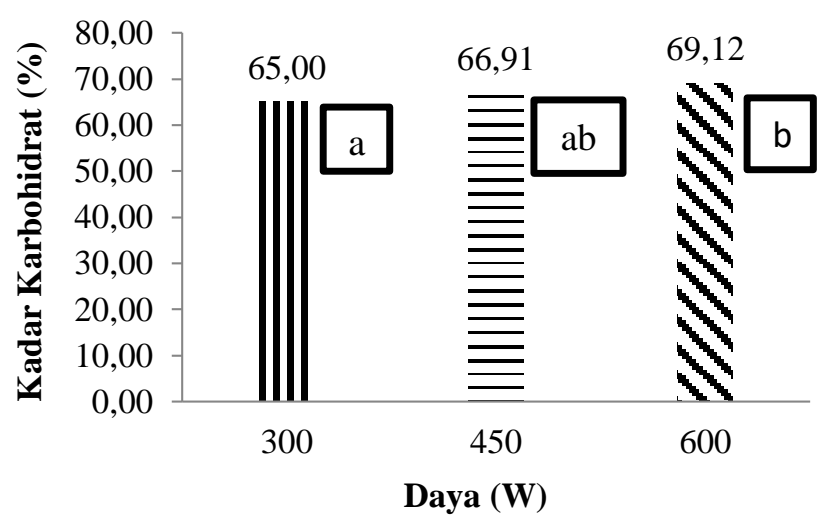

Gambar 5. Kadar Karbohidrat Gaplek Uwi Ungu Pada Pengeringan Microwave Akibat Pengaruh Variasi Daya.

\section{Warna Gaplek Uwi Ungu}

\section{Nilai L*a*b Gaplek Uwi Ungu}

Berdasarkan grafik data analisis warna gaplek uwi ungu diketahui bahwa nilai dari L pada perlakuan daya $300 \mathrm{~W}$ yaitu 86,33 , nilai dari warna L pada perlakuan $450 \mathrm{~W}$ yaitu 78,67 dan nilai warna L pada perlakuan $600 \mathrm{~W}$ yaitu sebesar 87,33. Dari hasil rerata pada setiap perlakuan dapat dilihat bahwa nilai L tertinggi yang didapatkan setelah perlakuan yaitu pada perlakuan daya $600 \mathrm{~W}$. Kemudian nilai warna L terendah didapatkan setelah perlakuan daya $450 \mathrm{~W}$. Nilai warna a tertinggi didapatkan pada perlakuan daya $450 \mathrm{~W}$. Kemudian nilai warna a terendah didapatkan pada perlakuan daya $600 \mathrm{~W}$. Nilai warna b tertinggi didapatkan pada perlakuan daya $600 \mathrm{~W}$ dan nilai warna $\mathrm{b}$ terendah didapatkan pada perlakuan daya $450 \mathrm{~W}$.

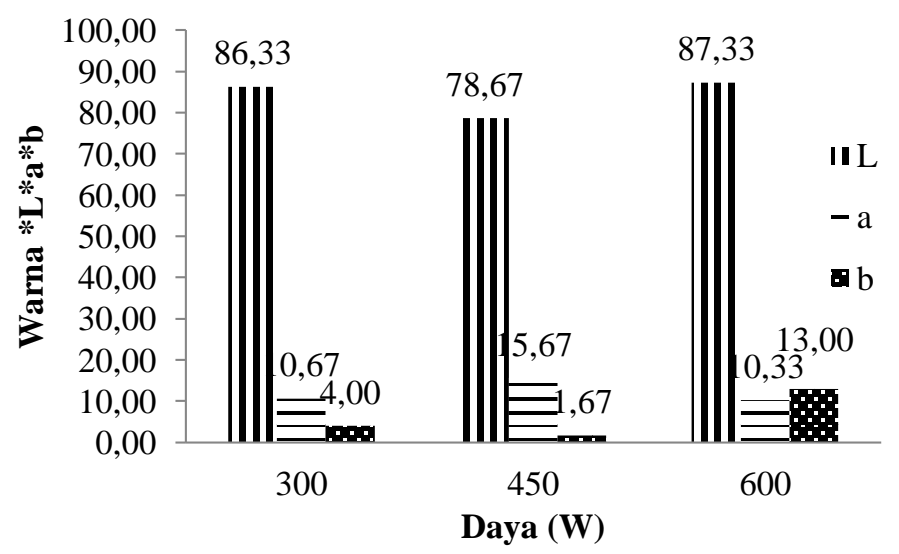

Gambar 6. Warna Gaplek Uwi Ungu Pada Pengeringan Microwave Akibat Pengaruh Variasi Daya.

\section{Warna Secara Organoleptik}

Berdasarkan grafik data warna gaplek uwi ungu yang didapatkan dari hasil penelitian ini yaitu 4,20 pada perlakuan $300 \mathrm{~W}, 4,23$ pada perlakuan $450 \mathrm{~W}$ dan 4,28 pada perlakuan $600 \mathrm{~W}$. Hasil uji hedonik terhadap warna gaplek uwi ungu mendapatkan skor sama pada daya $300 \mathrm{~W}, 450 \mathrm{~W}$ dan $600 \mathrm{~W}$ dengan skor 4 (suka). Panelis menyukai warna seluruh sample dengan nilai 4 yaitu suka. 


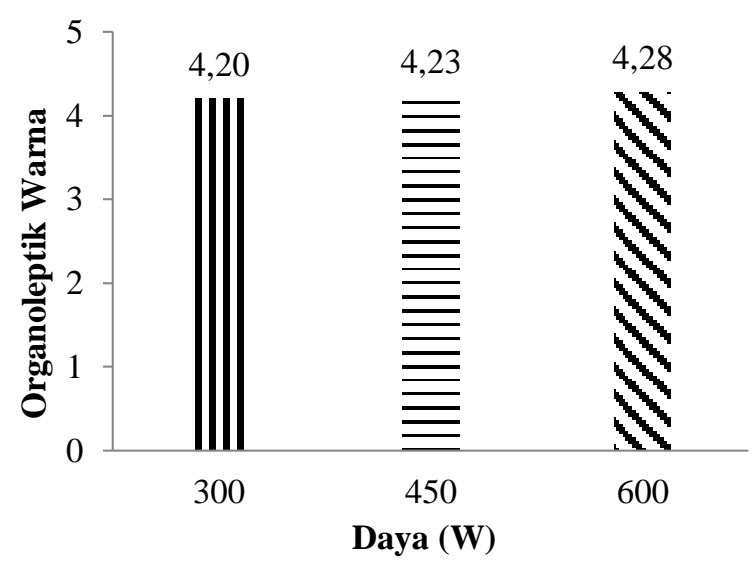

Gambar 7. Organoleptik Warna Gaplek Uwi Ungu Pada Pengeringan Microwave Akibat Pengaruh Variasi Daya.

\section{Warna Menurut Deskripsi}

Hasil analisis warna menurut deskripsi pada daya $300 \mathrm{~W}$ memiliki warna ungu pekat. Warna gaplek uwi ungu pada perlakuan daya $450 \mathrm{~W}$ menghasilkan warna ungu kecoklatan. Sedangkan warna pada perlakuan daya $600 \mathrm{~W}$ menghasilkan warna ungu pucat. Standar warna gaplek uwi ungu adalah uwi ungu segar atau warna ungu pekat, dimana warna ungu pekat terdapat pada daya $300 \mathrm{~W}$, maka semakin pekat warna ungunya kandungan antioksidan akan semakin banyak.

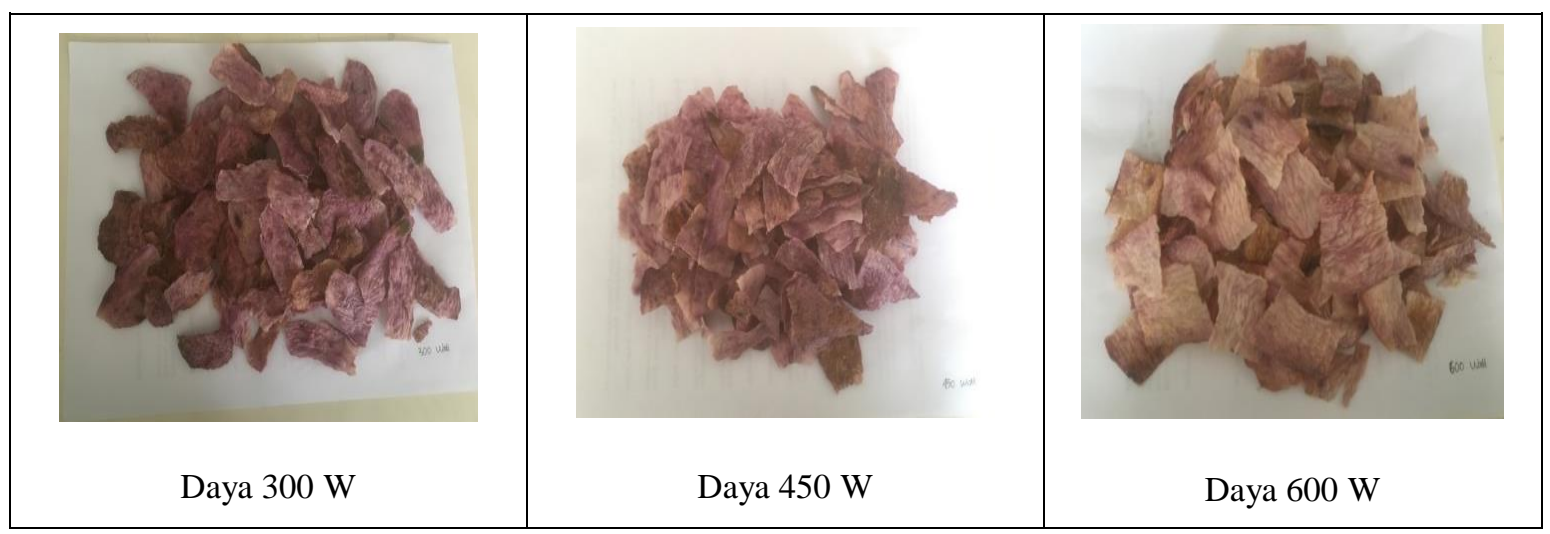

Gambar 8. Gaplek Uwi Ungu Hasil Pengeringan Dengan Oven Microwave

\section{Organoleptik Tekstur dan Aroma}

Berdasarkan grafik data tekstur gaplek uwi ungu yang didapatkan dari hasil penelitian ini yaitu 4,09 pada perlakuan $300 \mathrm{~W}, 4,15$ pada perlakuan $450 \mathrm{~W}$ dan 4,18 pada perlakuan $600 \mathrm{~W}$. Hasil uji hedonik terhadap tekstur gaplek uwi ungu mendapatkan skor sama pada daya $300 \mathrm{~W}, 450 \mathrm{~W}$ dan $600 \mathrm{~W}$ dengan skor 4 (suka). Panelis menyukai tekstur seluruh sample dengan niali 4 yaitu suka (Gambar 9).

Berdasarkan grafik data aroma gaplek uwi ungu yang didapatkan dari hasil penelitian ini yaitu 4,09 pada perlakuan $300 \mathrm{~W}, 3,91$ pada perlakuan $450 \mathrm{~W}$ dan 4,15 pada perlakuan $600 \mathrm{~W}$. Hasil uji hedonik terhadap aroma gaplek uwi ungu mendapatkan skor tertinggi yaitu pada daya $300 \mathrm{~W}$ dan $600 \mathrm{~W}$ dengan skor 4 (suka). Panelis menyukai aroma seluruh sample dengan niali 4 yaitu suka (Gambar 10). 


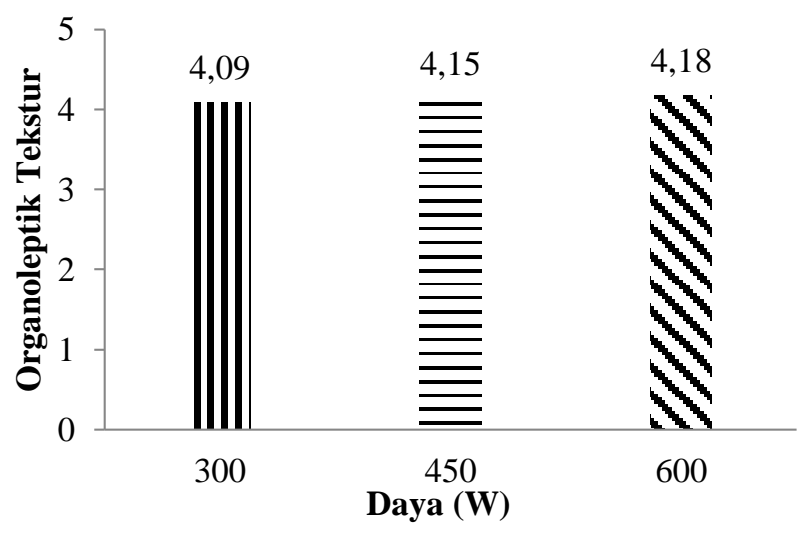

Gambar 9. Organoleptik Tekstur Gaplek Uwi Ungu Pada Pengeringan Microwave Akibat Pengaruh Variasi Daya.

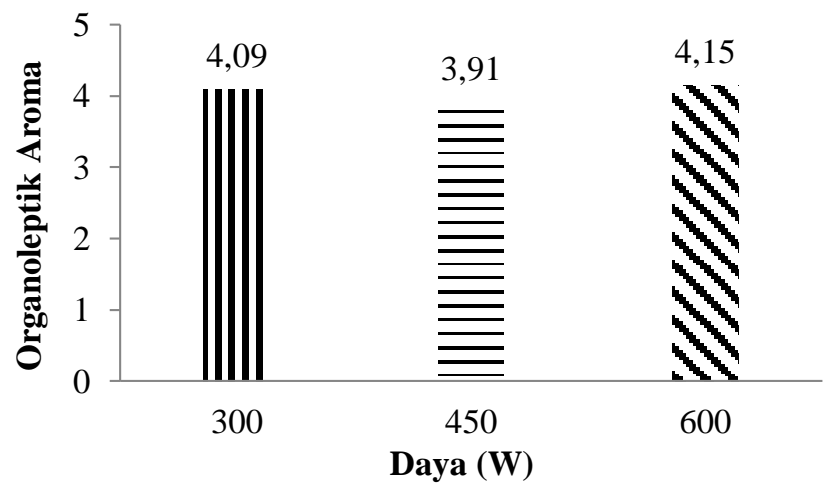

Gambar 1. Organoleptik Aroma Gaplek Uwi Ungu Pada Pengeringan Microwave Akibat Pengaruh Variasi Daya.

Hasil penelitian ini menunjukkan bahwa sampel gaplek uwi ungu pada semua perlakuan sudah memenuhi kadar air SNI di bawah 14\%. Namun demikian perlakuan terbaik adalah pada penggunaan daya $300 \mathrm{~W}$, dengan kadar air yang memenuhi standar SNI, rendemen tertinggi, kandungan vitamin $\mathrm{C}$ tertinggi dan warna gaplek paling ungu. Sehingga penelitian ini merekomendasikan daya $300 \mathrm{~W}$ sebagai daya yang baik. Hal tersebut dikarenakan pada penggunaan daya $300 \mathrm{~W}$ konsumsi energi listrik lebih sedikit dibandingkan daya yang lain dan juga pada pengeluaran biaya listrik lebih hemat.

\section{KESIMPULAN DAN SARAN}

Berdasarkan hasil penelitian dapat diambil simpulan bahwa perlakuan daya microwave memberi pengaruh nyata terhadap kadar air dan kadar karbohidrat. Namun perlakuan tersebut tidak memberi pengaruh nyata terhadap faktor lain yang diuji yaitu rendemen, kadar vitamin $\mathrm{C}$, warna dan uji organoleptik. Pemberian daya $300 \mathrm{~W}$ sangat direkomendasikan untuk proses pengeringan uwi ungu menggunakan oven microwave. 


\section{DAFTAR PUSTAKA}

AOAC. 1995. Official Methods of Analysis of The Association of Official Analytical Chemist. AOAC Inc. Washington.

Deman. 1997. Kimia Makanan. Edisi Kedua. Institut Teknologi Bandung. Bandung.

Dina, S. F., Farel, H. N., Himsar, A. 2013. Kajian Berbagai Metode Pengeringan Untuk Perbaikan Mutu Biji Kakao Indonesia. Jurnal Riset Industri. 7(1): 35-52.

Fauzi, M., N. Diniyah, A. S. Rusdianto dan D. E. Kuliahsari. 2017. Penggunaan Vitamin C dan Suhu Pengeringan Pada Pembuatan Chip (Irisan Kering) Labu Kuning LA3 (Cucurbita moschata). Jurnal Teknologi Hasil Pertanian Fakultas Pertanian. Universitas Jember. 108-115.

French, B. R. 2006. Food Plants Of Papua New Guinea: A Compedium. Tasmania West St. Australia.

Martunis. 2012. Pengaruh Suhu dan Lama Pengeringan Terhadap Kualitas dan Kuantitas Pati Kentang Varietas Granola. Jurnal Teknologi dan Industri Pertanian Indonesia. 4(3): 26-30.

Permadi, M. R., Huda O., Khafidurahman dan Agustianto. 2018. Perancangan Sistem Uji Sensori Makanan Dengan Pengujian Peference Test (Hedonik dan Mutu Hedonik).

Quoc, L. P. T. 2014. Optimization of The Pectin Extraction From Pomelo Peels by Oxalic Acid and Microwave. Banat's Jurnal of Biotechnology. Vietnam.

Siswantoro, B. Raharjo, N. Bintoro.,P. Hastuti. 2008. Model Matematik Transfer Panas Pada Penggorengan Menggunakan Pasir. Prosiding Seminar Nasional Teknik Pertanian 2008 Yogyakarta 18-19 November 2008.

Thamrin dan Kharisandi, A. 2011. Rancang Bangun Alat Pengering ubi Kayu Tipe Rak Dengan Memanfaatkan Energi Surya. Prosiding Seminar Nasional AvoER ke-3. Palembang.

Winarno, F. G. 1996. Teknologi Pengolahan Rumput Laut. Pustaka Sinar Harapan. Jakarta.

Wignyanto dan E. Lestari. 2015. Penerapan mesin pengering mekanis untuk penguawtan kapabilitas produksi pada kerupuk kentang sebagai upaya pemenuhan permintaan pasar. Journal of Innovation and Applied Technology. 1: 75-81. 